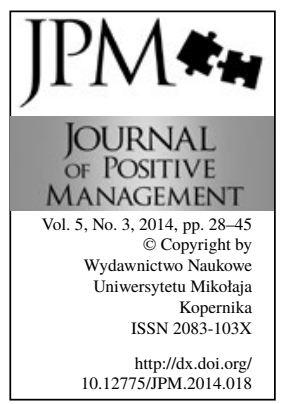

\title{
LEADERSHIP EMPOWERMENT BEHAVIOUR, WORK ENGAGEMENT AND TURNOVER INTENTION: THE ROLE OF PSYCHOLOGICAL EMPOWERMENT
}

\author{
Sonja de Klerk ${ }^{\mathrm{a}}$ \\ Marius W. Stander \\ Optentia Research Programme, North-West University, Vaal Campus, \\ South Africa \\ a e-mail: sonja.deklerk@sasol.com b e-mail: Marius.Stander@nwu.ac.za
}

\begin{abstract}
Research purpose: The purpose of this study was to investigate the relationship between leadership empowerment behavior, psychological empowerment, work engagement and turnover intention. The study further investigated whether psychological empowerment mediates the relationship between leadership empowerment behavior and turnover intention and work engagement respectively.
\end{abstract}

Research design, approach and method: A cross-sectional survey design was used with a convenience sample $(N=322)$. Confirmatory factor analysis was used to test whether the measures of the constructs were consistent with the understanding of the nature of the constructs and to test whether the data fitted the hypothesized measurement model. Structural Equation Modeling (SEM) was used to examine the structural relationships between the constructs.

Measuring instruments: The Leader Empowering Behavior Questionnaire, Measuring Empowerment, Work Engagement and Turnover Intention scales were administered.

Main findings: The results showed significant positive relationships between leadership empowerment behavior, psychological empowerment, work engagement and a negative correlation with turnover intention. Leadership empowerment behavior affected work engagement through psychological empowerment.

Practical implications: It is recommended that leadership discussions, training programs and individual coaching about leadership empowering behavior takes place.

Keywords: Talent management, leadership empowerment behavior, psychological empowerment, work engagement, turnover intention, positive organizations.

Paper type: Research paper 


\section{Introduction}

Managing human capital effectively provides a major competitive advantage for companies. Leaders need to be increasingly thoughtful and meticulous about monitoring their organization's human capital strategy (Ashford and Dieck, 2012; Bakker and Schaufeli, 2008). Recently, researchers and practitioners begun to optimize the potential benefits of positive psychology in the workplace to enhance corporate performance as well as employees' experience of work (Mills et al., 2013). According to Mills and others the concept Positive Psychology in the Workplace (PPW) incorporates Positive Organizational Behavior (POB) and Positive Organizational Scholarship (POS) and includes constructs such as leadership, empowerment and engagement.

Successful organizations have one major quality that sets them apart from ineffective organizations, namely dynamic and effective leadership (Druskat and Wheeler, 2003). In an era where nothing is more certain than change, leaders not only are responsible for guiding their employees through change (De Poel et al., 2012) but they increasingly play a critical role in building a strong pool of talent that is central to organizational success (Bhatnagar, 2007; Druskat and Wheeler, 2003; Luthans and Youssef, 2007; Yukl and Becker, 2006). Successful and effective leadership is important because it is closely associated with organizational outcomes such as enhanced employee attitudes, increased performance and motivation (Kelloway et al., 2012).

Traditionally dominated leadership practices should be balanced with leadership practices that are aimed at the empowerment of employees (Dewettinck and Van Ameijde, 2011). Leadership empowerment behavior (LEB) is seen as an enabling process, rather than a delegating process and is conceptualized as the ability of leaders to delegate authority, encourage accountability and selfdirected decision-making, developing skills and coaching of followers (Hakimi et al., 2010; Konczak et al., 2000).

Recent studies indicate leader empowering behaviors lead to various outcomes such as employee empowerment (Albrecht and Andreetta, 2011; Chen et al., 2011; Raub and Robert, 2010; Van Dierendonck and Dijkstra, 2012; Zhang and Bartol, 2010); work engagement (Mendes and Stander, 2011; Stander and Rothmann, 2010); and turnover intention (Albrecht and Andreetta, 2011; Chen et al., 2011; Van Schalkwyk et al., 2010). Just as positive psychology shifted the emphasis away from human deficiencies; leadership is focusing on positive human cognitions, feelings and expectations (Hannah, et al., 2009). Based on Cameron's (2008) conceptualization of the concept "positive", namely a focus on performance (accountable for outcomes), supportive (information sharing and development) and that what human beings consider to be good (empowerment), LEB can be classified as a positive approach to people management. 
LEADERSHIP

EMPOWERMENT

BEHAVIOUR

Sonja de Klerk

Marius W. Stander

\section{Leadership empowerment behavior (LEB)}

According to Srivastava et al. (2006), various leadership behaviors have been studied, but empowering leader behavior has assumed special importance. The six dimensions of leader empowering behavior, introduced by Konczak et al. (2000), are as follow: Delegation of authority where empowering leaders share information and knowledge with their followers to enable them to fully contribute and make quality decisions that are valuable to the organization (Hakimi et al., 2010). Accountability for outcomes focuses on leaders redistributing power and giving new responsibilities to followers, holding them accountable for outcomes (Hakimi et al., 2010; Konczak et al., 2000). Self-directed decision-making is described as allowing and involving subordinates to participate in problem solving processes (Konczak et al., 2000; Van Dierendonck and Dijkstra, 2012), enabling them to feel more empowered (Mills, et al., 2013). With information sharing, managers share information with employees and employees also share information with one another (Arnold et al., 2000; Konczak et al., 2000; Pearce and Sims, 2002). Furthermore, leaders play a vital role in skills development and coaching for innovative performance where they create opportunities for training and enhancing skills of subordinates (Konczak et al., 2000; Pearce and Sims, 2002). Cameron et al., (2011) identified development of human capital as one of the most predictive positive practices in terms of organizational effectiveness. Thus, there is a fundamental belief that leadership empowerment behavior stimulates psychological empowerment (Raub and Robert, 2010).

\section{Psychological empowerment}

Zbierowski (2011) named empowerment as one of the characteristics of positive management. Employee empowerment was first introduced in literature about 30 years ago by Kanter (1977). The fundamental belief of those campaigning empowerment is that empowerment initiatives improve employee performance, well-being, and positive attitudes (Forrester, 2000; Hempel et al., 2012; Mathieu et al., 2006; Wallace et al., 2011). Studies on empowerment conceptualized empowerment into structural empowerment which is concerned with organizational conditions, and psychological empowerment which focuses on employees' perceptions regarding empowerment (Conger and Kanungo, 1988; Menon, 2001; Spreitzer, 1995; Thomas and Velthouse, 1990).

Psychological empowerment, according to Spreitzer (1995), is an individual's subjective experience of empowerment based on cognitions about him/herself in relation to his/her work role and it is characterized as a four-dimensional psychological state consisting of meaning, competence, self-determination and impact. Together these four thoughts reveal one's active (an orientation in which the individual wishes and feels able to form his or her work role and environment), rather than inactive orientation to a work role (Spreitzer, 1995). 
Meaning is seen as a subjective assessment of the significance of the job and it reflects a sense of personal connection to work (Zhang and Bartol, 2010). High levels of meaning, according to Thomas and Velthouse (1990), result in increased commitment, involvement and concentration. Meaning is described by Arnold et al. (2000), as finding purpose in one's job that is greater than external outcomes of the work. Competence refers to a sense of self-efficacy or beliefs by individuals that they have the expertise and ability needed to perform their goals (Van Dierendonck and Dijkstra, 2012; Zhang and Bartol, 2010). High levels of competence result in an increased sense of confidence which in turn leads to higher effort and perseverance in the face of difficulties (Thomas and Velthouse, 1990).

Self-determination refers to a sense of control, autonomy and freedom of choice to fulfill tasks that make sense and to perform in ways that seem appropriate (Dewettinck and Van Ameijde, 2011). High levels of self-determination have a positive effect on individual and organisational levels (Liden et al., 2000). Impact refers to the belief of individuals that they possess the ability to influence the work environment and results at work (Dewettinck and Van Ameijde, 2011; Quinn and Spreitzer, 1997).

\section{Work engagement}

Kahn (1990: 694) defines personal engagement as "the harnessing of organization members" selves to their work roles; in engagement, people employ and express themselves physically, cognitively and emotionally during role performance". Work engagement is described by Schaufeli and Bakker (2004: 295) as "a positive, fulfilling, work-related state of mind that is characterized by vigor, dedication, and absorption". In this state one experiences difficulties with detaching oneself from work (Schaufeli and Bakker, 2004). If these views are combined, engagement is seen as the physical, cognitive, and emotional energy employees devote to their work, which helps them continue through difficulties and allows them to become engrossed in their work activities (Steger et al., 2013). According to Mills et al., (2013) the concept Positive Psychology in the Workplace (PPW) includes engagement as a construct.

According to Kahn (1990), the cognitive aspect of employee engagement deals with the employee's viewpoint on how and by whom the organization is led as well as working conditions within the organization; whereas the emotional element deals with how the employee experiences each of the three said factors. The physical aspect of Kahn's definition relates to the physical drives employed by individuals in order to carry out their organizational roles (Knight, 2011). Engagement, according to Kahn (1990), is strongest when all three dimensions are present. 
Figure 1.

Theoretically hypothesized model Source: own study.

\section{Turnover intention}

Turnover intention is a powerful predictor of an employee's future behavior and actual turnover (Carmeli and Weisberg, 2006; Harter et al., 2002; Park and Kim, 2009). The intention to leave is an individual's view that he/she would leave the organization (Kahumuza and Schlechter, 2008) and is viewed as the absolute last stage in the decision-making process of an employee to look for other employment (Park and Kim, 2009). Turnover intention is of critical importance to organizations as turnover can influence stability and productivity and it proves to be very costly (Firth et al., 2004; Siong et al., 2006). Understanding and managing the factors that influence employee turnover and the costs associated with it could be beneficial for companies (Du Plooy and Roodt, 2010).

\section{Aim and hypotheses}

The aim of this study is to explore the relationship between leadership empowerment behavior, psychological empowerment, work engagement and turnover intention in a chemical industry in South Africa.

Based on the model the following hypotheses have been formulated:

H1: Leadership empowerment behavior is positively related to psychological empowerment.

$\mathrm{H} 2$ : Leadership empowerment behavior is positively related to work engagement.

H3: Leadership empowerment behavior is negatively related to turnover intention.

H4: Leadership empowerment behavior affects turnover intention indirectly via psychological empowerment.

H5: Leadership empowerment behavior affects turnover intention indirectly via work engagement.

H6: Leadership empowerment behavior affects work engagement indirectly via psychological empowerment.

H7: Psychological empowerment affects turnover intention indirectly via work engagement.

Based on the review of literature, the hypothesized conceptual model of this study is graphically depicted in Figure 1.

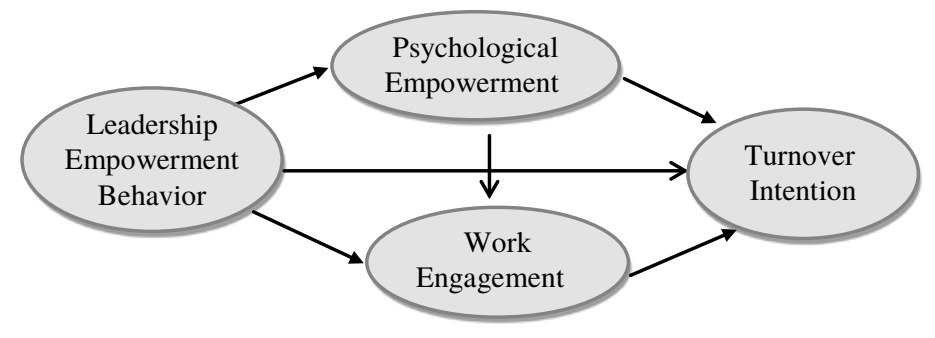


7.1 Research design

To achieve the objectives of the study, the researcher adopted a cross-sectional convenience survey design as all data was gathered at a single point in time (De Vos et al., 2011).

\subsection{Participants, procedure and ethics}

Informed consent was obtained from the governing body of the organization. Participation in the research was voluntary. All responses were anonymous and confidentiality was maintained at all times. The population consisted of 700 employees in various production areas. Three hundred and eighty five questionnaires were returned with 322 usable for data-analyses. Table 1 displays the characteristics of this sample of employees in a chemical industry in South Africa.

\begin{tabular}{|c|c|c|c|}
\hline Item & Category & Frequency & Percentage \\
\hline \multirow{2}{*}{ Gender } & Male & 298 & 92.5 \\
\hline & Female & 24 & 7.5 \\
\hline \multirow{5}{*}{ Cultural group } & African & 136 & 42.2 \\
\hline & White & 173 & 53.7 \\
\hline & Coloured & 3 & 0.9 \\
\hline & Indian & 7 & 2.2 \\
\hline & Other & 3 & 0.9 \\
\hline \multirow{5}{*}{ Age } & $18-25$ years & 32 & 9.9 \\
\hline & $26-35$ years & 103 & 32.0 \\
\hline & $36-45$ years & 65 & 20.2 \\
\hline & $46-55$ years & 93 & 28.9 \\
\hline & 56-65 years & 29 & 9.0 \\
\hline \multirow{6}{*}{ Qualifications } & Up to Grade 11 & 52 & 16.1 \\
\hline & Grade 12 & 95 & 29.5 \\
\hline & NQF 4 & 102 & 31.7 \\
\hline & Diploma & 43 & 13.4 \\
\hline & Degree & 18 & 5.6 \\
\hline & Degree+ & 12 & 3.7 \\
\hline
\end{tabular}

Sonja de Klerk Marius W. Stander 
LEADERSHIP EMPOWERMENT BEHAVIOUR

Sonja de Klerk Marius W. Stander

Table 1.

Continued

\begin{tabular}{|c|c|c|c|}
\hline Item & Category & Frequency & Percentage \\
\hline \multirow{6}{*}{ Department } & EG \& D & 136 & 42.2 \\
\hline & Water & 68 & 21.1 \\
\hline & Gas & 60 & 18.6 \\
\hline & Ammonia & 41 & 12.7 \\
\hline & HR & 13 & 4.0 \\
\hline & Other & 4 & 1.2 \\
\hline \multirow{5}{*}{ Level } & L4 \& up & 13 & 4.0 \\
\hline & L 5-6C & 32 & 9.9 \\
\hline & L 6-7 & 66 & 20.5 \\
\hline & L 8 & 136 & 42.2 \\
\hline & L 9-12 & 75 & 23.3 \\
\hline \multirow{5}{*}{ Years of service } & $1-5$ years & 99 & 30.7 \\
\hline & $6-10$ years & 55 & 17.1 \\
\hline & $11-20$ years & 52 & 16.1 \\
\hline & 21-30 years & 87 & 27.0 \\
\hline & $31-40$ years & 29 & 9.0 \\
\hline
\end{tabular}

The study sample consisted of $92,5 \%$ males, $53,7 \%$ were white with the majority $(32 \%)$ between the ages of 26-35. In general the sample is representative of the study population in terms of biographical characteristics.

\subsection{Measuring instruments}

The Leader Empowering Behavior Questionnaire (LEBQ; Konczak et al., 2000) was developed as a multidimensional 17-item scale with six subscales. The scale is rated from 1 (strongly disagree) to 7 (strongly agree). Higher scores indicated higher perceptions of leader empowering behaviors. The original scale consists of 17 items. An example of an item in the "authority" subscale is: "My manager gives me the authority I need to make decisions that improve work processes and procedures" (Konczak et al., 2000: 307). Two items from Arnold et al. (2000) were added to increase the number of items that demonstrated the "information sharing" element. Konczak et al. (2000) reported reliability coefficients that ranged between 0.82 and 0.88 with the exception of one subscale that measured 0.70 .

The Measuring Empowerment Questionnaire (MEQ; Spreitzer, 1995) is a 12-item scale that measures an individual's experience of psychological empowerment. This instrument is scored on a seven-point Likert scale, ranging from 1 (strongly disagree) to 7 (strongly agree). The scale consists of four subdimensions of psychological empowerment with three items each. Example of an 
item is "The work I do is very important to me" (meaning). The Cronbach alpha for the overall empowerment construct in Spreitzer's study indicated acceptable scores of 0.72 and 0.62 for the respective samples (Spreitzer, 1995).

The Work Engagement Scale (WES; Rothmann, 2010) measures work engagement on a seven-point frequency scale varying from 1 (almost never or never) to 7 (always or almost always). The items reflect the three components of Kahn's (1990) conceptualization of work engagement, namely cognitive, emotional and physical engagement. Cognitive engagement will be measured by three items (e.g. "I am very absorbed in my work"); emotional engagement will be measured by four items (e.g. "I am passionate about my work"); physical engagement will be measured by four items (e.g. "I feel alive and vital at work"). Alpha coefficients for the three scales of the WES were: Physical engagement $=0.80$; emotional engagement $=0.82$; and cognitive engagement $=0.78$ (Rothmann, 2010).

The Turnover Intention Scale (TIS; Sjöberg and Sverke, 2000) was used to measure respondents' intention to leave the company. The scale is a five-point Likert scale and ranges from 1 (strongly disagree) to 5 (strongly agree) with high scores measuring the respondents' probability to leave the organization. The scale consisted of three items and an example of an item is "If I was completely free to choose, I would leave this job". The Cronbach alpha coefficient for the TIS was 0.83 (Sjöberg and Sverke, 2000).

\subsection{Statistical analysis}

The statistical analysis was carried out with the SPSS 21 program (IBM Corporation, 2012) and the Mplus (7.11) statistical modeling program (Muthén and Muthén, 2013). Data was analyzed as categorical and therefor the WLSMV was used as estimator.

\section{Results}

\subsection{Testing the measurement model}

Using confirmatory factor analysis (CFA), the hypothesized measurement model was tested to assess whether each of the measurement items would load significantly onto the scales used in the study. CFA is driven by the theoretical relationships among the observed and unobserved variables (Schreiber, 2008). Five measurement models were tested. Model 1 consisted of four latent variables:

a) Leadership empowerment behavior consisted of five latent variables, b) Psychological empowerment consisted of four latent variables, c) Work engagement consisted of three latent variables and d) Turnover intention was measured by three observed variables. Model 1 was used as a baseline model to decide if the other four models represented a statistically significant improvement. The fit statistics for testing the various models are presented in Table 2. 
Table 2.

Fit Statistics of Measurement Models
Table 3.

Descriptive Statistics, Reliability and Pearson Correlations of the Scales $(N=322)$

\begin{tabular}{lccccccc}
\hline Model & $\boldsymbol{\chi}^{\mathbf{2}}$ & df & RMSEA & CFI & TLI & AIC & BIC \\
\hline Model 1 & 2146.48 & 801 & 0.07 & 0.95 & 0.95 & 40852.45 & 41395.98 \\
\hline Model 2 & 9667.31 & 819 & 0.18 & 0.70 & 0.68 & 45980.80 & 46456.39 \\
\hline Model 3 & 2805.17 & 806 & 0.09 & 0.93 & 0.93 & 41626.34 & 42151.00 \\
\hline Model 4 & 2867.83 & 805 & 0.09 & 0.93 & 0.92 & 41903.50 & 42431.94 \\
\hline Model 5 & 2252.12 & 804 & 0.08 & 0.95 & 0.95 & 41045.58 & 41577.79 \\
\hline
\end{tabular}

$d f=$ degrees of freedom; TLI = Tucker-Lewis Index; CFI = Comparative Fit Index;

RMSEA = Root Mean Square Error of Approximation

A $\chi^{2}$ value of $2146.48(d f=801)$ was obtained for model 1. TLI $=0.95$, CFI $=0.95$, and RMSEA $=0.07$. The hypothesized model had an acceptable fit with the data. Standardized coefficients from items to factors ranged from 0.72 to 0.99 . The results indicated that the relationship between each observed variable and its individual construct was statistically significant $(p<0.01)$, establishing the relationship between indicators and constructs (Hair et al., 2010). AIC and BIC values were calculated and comparison of these values showed that Models 2-5 had bigger values. AIC and BIC values are the best indicators for model fit, with the lowest values indicating the best fit between compared models (Muthén and Muthén, 2013).

\subsection{Testing the structural model}

8.2.1 Descriptive STATistics, alpha coefficients and correlations. The descriptive statistics, reliability coefficients and correlations are illustrated in Table 3.

\begin{tabular}{|c|c|c|c|c|c|c|c|c|c|c|c|c|c|c|c|c|}
\hline \multicolumn{2}{|c|}{ Variable } & \multirow{2}{*}{$\begin{array}{c}\text { Mean } \\
4.87\end{array}$} & \multirow{2}{*}{$\begin{array}{c}\text { SD } \\
1.62 \\
\end{array}$} & \multirow{2}{*}{$\begin{array}{c}\boldsymbol{\rho} \\
0.95\end{array}$} & \multirow[t]{2}{*}{1} & \multirow[t]{2}{*}{2} & \multirow[t]{2}{*}{3} & \multirow[t]{2}{*}{4} & \multirow[t]{2}{*}{5} & \multirow[t]{2}{*}{6} & \multirow[t]{2}{*}{7} & \multirow[t]{2}{*}{8} & \multirow[t]{2}{*}{9} & \multirow[t]{2}{*}{10} & \multirow[t]{2}{*}{11} & \multirow[t]{2}{*}{12} \\
\hline 1 & LEBAUT & & & & & & & & & & & & & & & \\
\hline 2 & LEBACC & 5.58 & 1.36 & 0.87 & $0.63^{* *}$ & - & - & - & - & - & - & - & - & - & - & - \\
\hline 3 & LEBDEC & 4.99 & 1.60 & 0.90 & $0.73^{* *}$ & $0.66^{* * *}$ & - & - & - & - & - & - & - & - & - & - \\
\hline 4 & LEBINF & 5.29 & 1.60 & 0.94 & $0.76^{* * *}$ & $0.69^{* * *}$ & $0.80^{* *}$ & - & - & - & - & - & - & - & - & - \\
\hline 5 & LEBDEV & 4.75 & 1.46 & 0.89 & $0.74^{* * *}$ & $0.67^{* * *}$ & $0.78^{* *}$ & $0.81^{* * *}$ & - & - & - & - & - & - & - & - \\
\hline 6 & PEMEAN & 5.81 & 1.39 & 0.95 & $0.39^{* *}$ & $0.36^{* * *}$ & $0.41^{* *}$ & $0.43^{* *}$ & $0.42^{* * *}$ & - & - & - & - & - & - & - \\
\hline 7 & PECOMP & 6.15 & 1.02 & 0.90 & $0.40^{* * *}$ & $0.36^{* * *}$ & $0.42^{* *}$ & $0.44^{* *}$ & $0.43^{* *}$ & $0.61^{* * *}$ & - & - & - & - & - & - \\
\hline 8 & PEIMPACT & 4.81 & 1.60 & 0.92 & $0.36^{* * *}$ & $0.33^{* *}$ & $0.38^{* *}$ & $0.39^{* * *}$ & $0.39^{* *}$ & $0.55^{* *}$ & $0.56^{* *}$ & - & - & - & - & - \\
\hline 9 & PESELF & 5.71 & 1.22 & 0.88 & $0.44^{* * *}$ & $0.40^{* * *}$ & $0.46^{* *}$ & $0.48^{* *}$ & $0.47^{* * *}$ & $0.67^{* * *}$ & $0.68^{* *}$ & $0.62^{* *}$ & - & - & - & - \\
\hline 10 & CENG & 4.57 & 1.30 & 0.78 & $0.26^{* *}$ & $0.24^{* * *}$ & $0.28^{* *}$ & $0.29^{* *}$ & $0.28^{* *}$ & $0.40^{* *}$ & $0.40^{* *}$ & $0.36^{* *}$ & $0.44^{* *}$ & - & - & - \\
\hline 11 & EENG & 5.61 & 1.41 & 0.96 & $0.36^{* *}$ & $0.32^{* * *}$ & $0.38^{* *}$ & $0.39^{* *}$ & $0.38^{* * *}$ & $0.54^{* * *}$ & $0.55^{* *}$ & $0.5^{* *}$ & $0.60^{\text {*** }}$ & $0.69^{* *}$ & - & - \\
\hline 12 & PENG & 5.28 & 1.42 & 0.95 & $0.35^{* * *}$ & $0.32^{* * *}$ & $0.37^{* *}$ & $0.38^{* * *}$ & $0.38^{* * *}$ & $0.53^{* *}$ & $0.54^{* *}$ & $0.49^{* * *}$ & $0.59^{* * *}$ & $0.68^{* *}$ & $0.93^{* *}$ & - \\
\hline 13 & Total TI & 3.14 & 1.42 & 0.93 & $-0.36^{* *}$ & $-0.33^{* * *}$ & $-0.38^{* *}$ & $-0.39^{* *}$ & $-0.39^{* * *}$ & $-0.20^{* *}$ & $-0.20^{* *}$ & $-0.19^{* *}$ & $-0.23^{* *}$ & $-0.02^{* *}$ & $-0.27^{* * *}$ & $-0.27^{* * *}$ \\
\hline
\end{tabular}

* Correlation is significant at the 0.05 level (2-tailed) ${ }^{* * *}$ Correlation is significant at the 0.01 level (2-tailed) 
8.2.2 Evaluating the hypothesized MOdel. The structural model was tested using Model 1 (see Table 2), which was the best fitting and most parsimonious measurement model. The hypothesized relationships were tested using latent variable modeling as implemented by Mplus 7 (Muthén and Muthén, 2004). Results indicated a fair fit of the structural model compared to the measurement model $\left(\chi^{2}=2146.48, d f=801\right.$, TLI $=0.95, \mathrm{CFI}=0.95$, and RMSEA $\left.=0.07\right)$. Five competing models were tested: psychological empowerment to work engagement was constraint to zero. The standardized path coefficients estimated by Mplus are illustrated in Table 4 and Figure 2. Table 4 indicates the fit statistics for Model 1 that fitted the data best.

\begin{tabular}{cccccc}
\hline Model & $\chi^{\mathbf{2}}$ & Df & TLI & CFI & RMSEA \\
\hline Model 1 & 2146.48 & 801 & 0.02 & 0.95 & 0.07 \\
\hline
\end{tabular}

$d f=$ degrees of freedom; TLI = Tucker-Lewis; CFI = Comparative Fit Index;

RMSEA $=$ Root Mean Square Error of Approximation

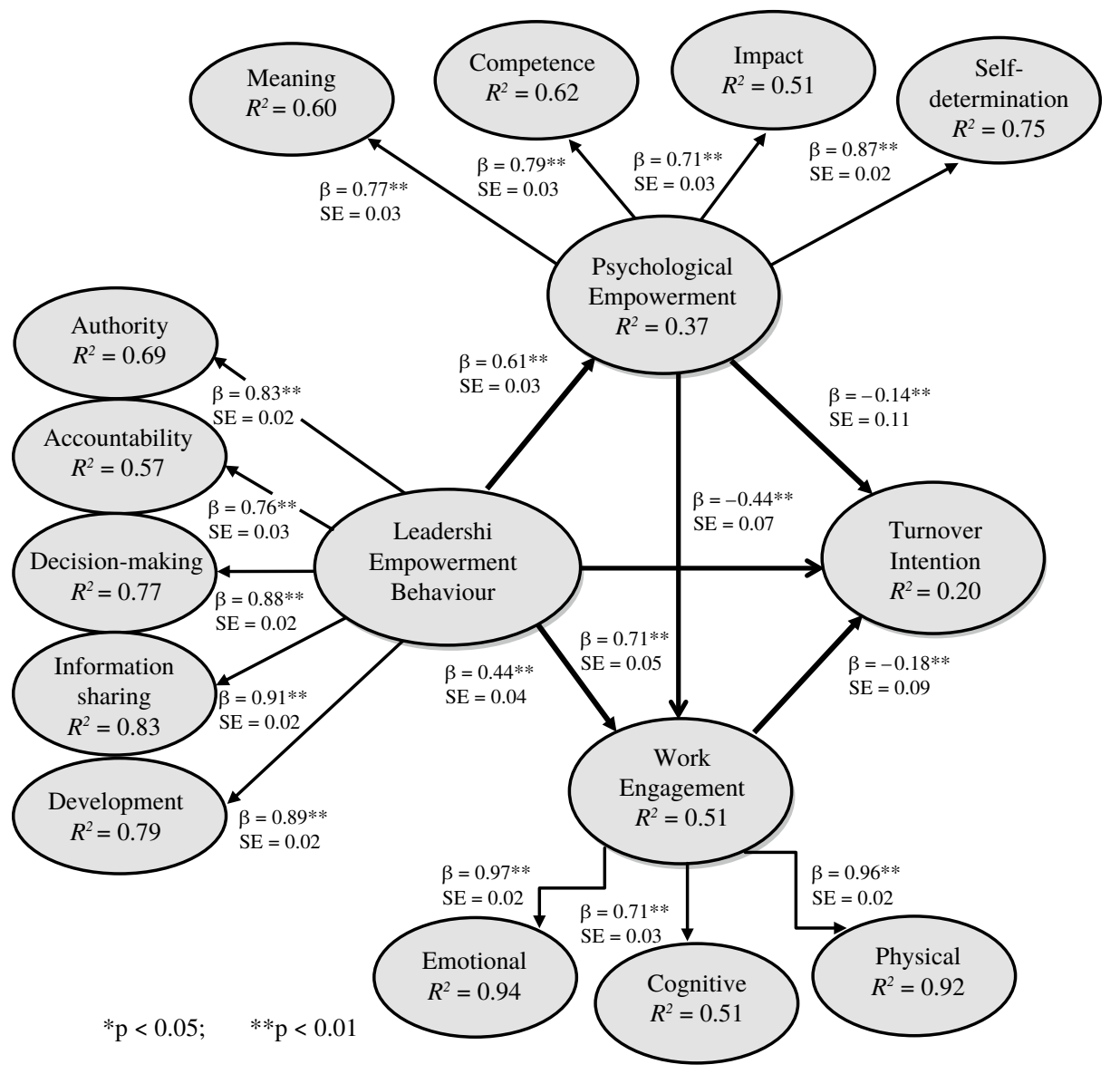

Figure 2.

The hypothesized model

- 37 
LEADERSHIP EMPOWERMENT BEHAVIOUR

Sonja de Klerk Marius W. Stander

Table 5.

Different Testing of Competing Structural Models
The following changes in chi-square $\left(\Delta \chi^{2}\right)$ were found: Model $2 \mathrm{~b}\left(\Delta \chi^{2}=5.71\right.$, $\Delta d f=1, p<0.02)$, Model 2c $\left(\Delta \chi^{2}=1.59, \Delta d f=1, p<0.21\right)$, Model 2d $\left(\Delta \chi^{2}=38.65\right.$, $\left.{ }_{\Delta} d f=1, p<0.00\right)$, Model 2e $\left(\Delta \chi^{2}=5.71,{ }_{\Delta} d f=1, p<0.02\right)$, and Model $2 \mathrm{f}\left(\Delta \chi^{2}=\right.$ 3.00, $\Delta d f=2, p<0.22)$.

\begin{tabular}{lccc}
\hline Model & \multicolumn{1}{c}{$\boldsymbol{\chi}^{\mathbf{2}}$} & ${ }_{\boldsymbol{\Delta}}$ df & p value \\
\hline Model 2 & 39.65 & 1 & 0.00 \\
\hline Model 3 & 115.21 & 1 & 0.00 \\
\hline Model 4 & 2.59 & 1 & 0.11 \\
\hline Model 5 & 5.71 & 1 & 0.02 \\
\hline
\end{tabular}

The obtained relationships of the best fitting and most parsimonious structural model (Model 1a) are discussed with reference to the hypotheses of this study.

Hypothesis 1: The ML-estimated equation accounted for a large proportion of the variance in psychological empowerment $\left(R^{2}=0.37\right)$. Hypothesis 1 is, therefore, accepted.

Hypothesis 2: The ML-estimated equation accounted for a large proportion of the variance in work engagement $\left(R^{2}=0.51\right)$. These results provided support for Hypothesis 2.

Hypothesis 3: It must be kept in mind that high turnover intention is negative. These results provided support for Hypothesis 3 .

Hypothesis 4: To determine whether relationships in the model were indirectly affected by psychological empowerment, the bias-corrected confidence intervals were calculated using bootstrapping with 5000 samples (Hayes, 2009). Table 6 shows that the bootstrap-estimated indirect effects of psychological empowerment on leadership empowerment behavior and turnover intention were statistically significant $(p<0.01)$, but the 95\% CIs included zeros (Preacher and Hayes, 2008). This suggests that psychological empowerment does not have an indirect effect on the relationship and Hypothesis 4 could thus not be accepted.

Hypothesis 5: According to Table 6 the indirect effects of work engagement on leadership empowerment behavior and turnover intention were statistically significant $(p<0.01)$, but the 95\% CIs included zeros. Leadership empowerment behavior does not affect turnover intention indirectly via work engagement and Hypothesis 5 could thus not be accepted.

Hypothesis 6: Table 6 shows that the bootstrap-estimated indirect effects of psychological empowerment on leadership empowerment behavior and work engagement were significant $(p<0.01)$ and did not include zeros. This suggests that leadership empowerment did have an indirect 
effect on work engagement via psychological empowerment, supporting Hypothesis.

Hypothesis 7: Table 6 shows that the bootstrap-estimated indirect effects of work engagement on psychological empowerment and turnover intention were significant $(p<0.01)$ and did include zeros. This suggests that psychological empowerment does not have an indirect effect on the relationship and Hypothesis 7 could thus not be accepted.

\begin{tabular}{lcccccc}
\hline & \multicolumn{3}{c}{ PE } & \multicolumn{3}{c}{ ENG } \\
\hline Scale & Estimate & SE & 95\% CI & Estimate & SE & 95\% CI \\
\hline Turnover Intention (LEB) & 0.08 & 0.08 & {$[-0.08,0.24]$} & -0.01 & 0.01 & {$[-0.03,0.03]$} \\
\hline Turnover Intention (PE) & & & & -0.13 & 0.08 & {$[-0.28,0.02]$} \\
\hline Work Engagement (LEB) & $0.43^{* *}$ & 0.06 & {$[0.32,0.55]$} & & & \\
\hline$* * \mathrm{p}<0.01$ & & & & & &
\end{tabular}

\section{Discussion}

Results showed that leadership empowerment behavior correlated statistically significantly with psychological empowerment and work engagement and negatively with turnover intention. The results implied that leadership empowerment behavior influences employees' perceptions of and experiences in the work environment to a great extent. When leaders empower their employees they will feel more competent and in control and they will experience meaning in their work. The results of this study are in line with previous studies and confirm that when leaders empower rather than control their employees, they will experience psychological empowerment (Appelbaum et al., 1999; Greasley et al., 2008; Lawler et al., 2001; Mendes and Stander, 2010; Raub and Robert, 2010).

The results support the research of Gregory et al. (2010), which suggests that employees experiencing psychological empowerment feel that their contributions are meaningful and that they possess the ability to shape their work environment. Bhatnagar (2012) and De Villiers and Stander (2011) in their studies found similar results and are of the opinion that psychologically empowered employees are more engaged, more loyal and less likely to engage in turnover intention. Employees who are able to connect with the organization and its leaders are seen to be physically, cognitively and emotionally engaged. Having an engaged workforce brings many advantages for organizations. Engagement levels are predictive of performance levels of employees (Bakker and Bal, 2010); indicating that employees are energetic (Maslach and Leiter, 2005); engagement also being a significant predictor of turnover intention (Albrecht and Andreetta, 2011; Du Plooy and Roodt, 2010).
LEADERSHIP EMPOWERMENT BEHAVIOUR

Sonja de Klerk Marius W. Stander

\section{Table 6.} Standardized Indirect Effects of LEB and Psychological Empowerment 
LEADERSHIP EMPOWERMENT BEHAVIOUR

Sonja de Klerk Marius W. Stander
The results of this study show that leadership empowerment behavior, psychological empowerment and engagement predicted $20 \%$ of the variance in turnover intention. Organizations need to focus on development of leaders who are able to empower and lift engagement levels which will result in retention of talent. Seibert et al. (2011), Bhatnager (2012), and Du Plooy and Roodt (2010) found that engagement was a significant predictor of turnover intention.

The results in this study confirmed that psychological empowerment had an indirect effect on the relationship between leadership empowerment behavior and work engagement. This implies that increased leadership empowerment behavior will result in higher levels of psychological empowerment which, in turn, will increase work engagement. When leaders thus increase employees' degree of authority, decision-making and accountability, share information and support, develop and coach employees for innovative performance, employees will experience feelings of control. When individuals feel that their inputs are valued and that they make a meaningful contribution to the business strategy (impact), they will feel more engaged.

\section{Limitations and future directions of research, practical recommendations}

The results support previous knowledge indicating the importance of leadership development to increase organizational effectiveness and employee well-being. The LEB concept gives a clear frame work to develop empowering leaders by firstly focusing on their strengths and secondly coaching them to optimize direct reports strengths. Cameron (2013) identified four strategies to produce extraordinary performance in organizations: creation of a positive climate; positive relationships; positive communication and positive meaning. This is attainable if leaders are developed to delegate authority, keep people accountable for results, allow self-directed decision making, inform and develop them.

A cross-sectional research design was utilised which limits the ability of this study to determine cause-and-effect relationships. The study focuses only on one company, limiting the generalization of the results. It is recommended that the constructs used in this study be investigated in the other organisations, employing a longitudinal design. It would be beneficial to investigate the effects that leadership empowerment behaviour, psychological empowerment and work engagement have on other outcomes such as performance, absenteeism, wellness, trust and safety; as these factors are central to reaching organisational success. It is further recommended that different positive leadership styles such as authentic and transformational be investigated in relation to psychological empowerment, work engagement and its outcomes on turnover intention. 


\section{References}

Albrecht, L.S., Andreetta, M. (2011), “The influence of empowering leadership, empowerment and engagement on affective commitment and turnover intentions in community health service workers: Test of a model", Leadership in Health Services, Vol. 24 No. 3, pp. 228-237. DOI:http://dx.doi.org/10.1108/17511871111151126

Appelbaum, S.H., Hébert, D., Le Roux, S. (1999), "Empowerment: Power, culture and leadership - A strategy or fad for the millennium?", Journal of Workplace Learning, Vol. 11 No. 7, pp. 233-254. DOI:http://dx.doi.org/10.1108/13665629910291929

Arnold, J.A., Arad, S., Rhoades, J.A., Drasgow, F. (2000), "The empowering leadership questionnaire: The construction and validation of a new scale for measuring leader behaviors", Journal of Organizational Behavior, Vol. 21 No. 3, pp. 249-269. DOI:http://dx.doi.org/10.1002/(SICI)1099-1379(200005)21:3\%3C249::AID-JOB 10\%3E3.0.CO;2-\% 23

Ashford, O., Dieck, E. (2012), "A heightened interest in human capital as strategic asset”, available at: http://www.directorship.com/a-heightened-interest-in-humancapital-as-a-strategic-asset (accessed 22 July 2013).

Bakker, A.B., Bal, P.M. (2010), "Weekly work engagement and performance: A study among starting teachers", Journal of Occupational and Organizational Psychology, Vol. 83 No. 1, pp. 189-206. DOI:http://dx.doi.org/10.1348/096317909X402596

Bakker, A.B., Schaufeli, W.B. (2008), "Positive organizational behavior: Engaged employees in flourishing organizations", Journal of Organizational Behavior, Vol. 29 No. 2, pp. 147-154. DOI:http://dx.doi.org/10.1002/job.515

Bhatnagar, J. (2007), “Talent management strategy of employee engagement in Indian ITES employees: Key to retention”, Employee Relations, Vol. 29 No. 6, pp. 640-663. DOI:http://dx.doi.org/10.1108/01425450710826122

Bhatnagar, J. (2012), "Management of innovation: Role of psychological empowerment, work engagement and turnover intention in the Indian context", Journal of Human Resource Management, Vol. 23 No. 5, pp. 928-951. DOI:http://dx.doi.org/10.1080/ 09585192.2012 .651313

Cameron.K., Mora, C., Leutscher, T., Calarco, M. (2011), “ Effects of Positive Practices on Organizational Efeectiveness", Journal of Applied Behavioral Science, Vol. 47 No. 3, pp. 266-308. DOI:http://dx.doi.org/10.1177/0021886310395514

Cameron, K. (2008), Positive leadership: Strategies for extraordinary performance, Berrett-Koehler, Inc., San Francisco, CA.

Cameron, K. (2013), Practising positive leadership: Tools and techniques that create extraordinary results, Berrett-Koehler, Inc., San Francisco, CA.

Carmeli, A., Weisberg, J. (2006), "Exploring turnover intentions among three professional groups of employees", Human Resource Development International, Vol. 9 No. 2, pp. 191-206. DOI:http://dx.doi.org/10.1080/13678860600616305

Chen, G., Sharma, P.N., Edinger, S., Shapiro, D.L., Farh, J.L. (2011), "Motivating and demotivating forces in teams: Cross-level influences of empowering leadership and relationship conflict". Journal of Applied Psychology, Vol. 96 No. 3, pp. 541-557. DOI:http://dx.doi.org/10.1037/a0021886

Conger, J.A., Kanungo, R.N. (1988), “The empowerment process: Integrating theory and
LEADERSHIP

EMPOWERMENT BEHAVIOUR

Sonja de Klerk Marius W. Stander 
LEADERSHIP EMPOWERMENT BEHAVIOUR

Sonja de Klerk Marius W. Stander practice", Academy of Management Review, Vol. 13 No. 3, pp. 471-482. DOI:http:// dx.doi.org/10.2307/258093

De Poel, F.M., Stoker, J.I., Van der Zee, K.I. (2012), “Climate control? The relationship between leadership, climate for change, and work outcomes", The International Journal of Human Resources Management, Vol. 23 No. 4, pp. 694-713. DOI:http:// dx.doi.org/10.1080/09585192.2011.561228

De Villiers, J.R., Stander, M.W. (2011), "Psychological empowerment, work engagement and turnover intention: The role of leader relations and role clarity in a financial institution", Journal of Psychology in Africa, Vol. 21 No. 3, pp. 405-412.

De Vos, A.S. (Ed.), Strydom, H., Fouché, C.B., Delport, C.S.L. (2011), Research at grass roots: For the social sciences and human service profession, Van Schaik Publishers, Pretoria, SA.

Dewettinck, K., Van Ameijde, M. (2011), "Linking leadership empowerment behavior to employee attitudes and behavioral intentions", Personnel Review, Vol. 40 No. 3, pp. 284-305. DOI:http://dx.doi.org/10.1108/00483481111118621

Druskat, V.U., Wheeler, J.V. (2003), "Managing from the boundary: The effective leadership of self-managing work teams", Academy of Management Journal, Vol. 46 No. 4, pp. 435-457. DOI:http://dx.doi.org/10.2307/30040637

Du Plooy, J., Roodt, G. (2010), "Work engagement, burnout and related constructs as predictors of turnover intentions", South African Journal of Industrial Psychology, Vol. 36 No. 1, pp. 1-13. DOI:http://dx.doi.org/10.4102/sajip.v36i1.910

Firth, L., Mellor, D.L., Moore, K.A., Loquet, C. (2004), "How can managers reduce employee intention to quit?", Journal of Managerial Psychology, Vol. 19 No. 2, pp. 170-187. DOI:http://dx.doi.org/10.1108/02683940410526127

Forrester, R. (2000), "Empowerment: Rejuvenating a potent idea", Academy of Management Executive, Vol. 14 No. 3, pp. 67-80. DOI:http://dx.doi.org/10.5465/ AME.2000.4468067

Greasley, K., Bryman, A., Dainty, A., Price, A., Naismith, N., Soetanto, R. (2008), "Understanding empowerment from an employee perspective", Team Performance Management, Vol. 14 No. 1, pp. 39-55. DOI:http://dx.doi.org/10.1108/135275908108 60195

Gregory, B.T., Albritton, M.D., Osmonbekov, T. (2010), “The mediating role of psychological empowerment on the relationships between P-O fit, job satisfaction, and in-role performance", Journal of Business Psychology, Vol. 25 No. 4, pp. 639-647. DOI:http://dx.doi.org/10.1007/s10869-010-9156-7

Hair, J.F., Black, W.C., Babin, B.J., Anderson, R.E. (2010), Multivariate data analysis: A global perspective, Upper Saddle River, Pearson Education, New Jersey.

Hakimi, N., Van Knippenberg, D., Giessner, S. (2010), "Leader empowering behavior: The leader's perspective", British Journal of Management, Vol. 21 No. 3, pp. 701-716. DOI:http://dx.doi.org/10.1111/j.1467-8551.2010.00703.x

Hannah, S.T., Woolfolk, R.L., Lord, R.G. (2009), "Leader self-structure: A framework for positive leadership", Journal of Organizational Behavior, Vol. 30 No. 2, pp. 269-290. DOI:http://dx.doi.org/10.1002/job.586

Harter, J.K., Schmidt, F.L., Hayes, T.L. (2002), "Business-unit level relationship between employee satisfaction, employee engagement, and business outcomes: A meta- 
analysis”, Journal of Applied Psychology, Vol. 87 No. 2, pp. 268-279. DOI:http:// dx.doi.org/10.1037/0021-9010.87.2.268

Hayes, A.F. (2009), "Beyond Baron and Kenny: Statistical mediation analysis in the new millennium", Communication Monographs, Vol. 76 No. 4, pp. 408-420.

Hempel, P.S., Zhang, Z., Han, Y. (2012), "Team empowerment and the organizational context: Decentralization and the contrasting effects of formalization", Journal of Management, Vol. 38 No. 2, pp. 475-501.

IBM Corporation. (2012), "IBM SPSS statistics for Windows, version 21.0”, Armonk, NY, IBM Corporation. [computer software].

Kahn, W.A. (1990), "Psychological conditions of personal engagement and disengagement at work", Academy of Management Journal, Vol. 33 No. 4, pp. 692-724. DOI:http://dx.doi.org/10.2307/256287

Kahumuza, J., Schlechter, A.F. (2008), "Examining the direct and some mediated relationships between perceived support and intention to quit", Management Dynamics, Vol. 17 No. 3, pp. 2-19.

Kanter, R.M. (1977), Men and women of the corporation, Basic Books, New York, NY.

Kelloway, E.K., Turner, N., Barling, J., Loughlin, C. (2012), “Transformational leadership and employee psychological well-being: The mediating role of employee trust in leadership", Work and Stress: An International Journal of Work, Health and Organizations, Vol. 26 No. 1, pp. 39-55. DOI:http://dx.doi.org/10.1080/02678373.2012.660774

Knight, R. (2011), “Employee engagement: A study of employee engagement at Topaz's South Dublin region service stations", Master's Thesis, National College of Ireland, Dublin.

Konczak, L.J., Stelly, D.J., Trusty, M.L. (2000), "Defining and measuring empowerment leader behaviors: Development of an upward feedback instrument", Educational and Psychological Measurement, Vol. 60 No. 2, pp. 301-313.

Lawler, E.E., Mohrman, S.A., Benson, G. (2001), Organizing for high performance: Employee involvement, TQM, reengineering, and knowledge management in the Fortune 1000, Jossey-Bass, San Francisco, CA.

Liden, R.C., Wayne, S.J., Sparrowe, R.T. (2000), "An examination of the mediating role of psychological empowerment on the relations between the job, interpersonal relationships, and work outcomes", Journal of Applied Psychology, Vol. 85 No. 3, pp. 407-416. DOI:http://dx.doi.org/10.1037/0021-9010.85.3.407

Luthans, F., Youssef, C.M. (2007), "Emerging positive organizational behavior", Journal of Management, Vol. 33 No. 3, pp. 321-349. DOI:http://dx.doi. org/10.1177/0149206307300814

Mathieu, J.E., Gilson, L.L., Ruddy, T.M. (2006), "Empowerment and team effectiveness: An empirical test of an integrated model", Journal of Applied Psychology, Vol. 91 No. 1, pp. 97-108. DOI:http://dx.doi.org/10.1037/0021-9010.91.1.97

Maslach, C., Leiter, M.P. (2005), "Stress and burnout: The critical research", in: Cooper, C.L. (Ed.), Handbook of stress medicine and health, CRC Press, London, UK, pp. $155-172$.

Mendes, F., Stander, M.W. (2011), "Positive organisation: The role of leader behaviour in work engagement and retention", South African Journal of Industrial Psychology, Vol. 37 No. 1, pp. 1-13. DOI:http://dx.doi.org/10.4102/sajip.v38i1.900 
LEADERSHIP EMPOWERMENT BEHAVIOUR

Sonja de Klerk

Marius W. Stander
Menon, S.T. (2001), "Employee empowerment: An integrative psychological approach", Applied Psychology: An International Review Vol. 50 No. 1, pp. 153-180. DOI:http:// dx.doi.org/10.1111/1464-0597.00052

Mills, M J., Fleck, C.R., Kozikowski, A. (2013), "Positive psychology at work: A conceptual review, state-of-practice assessment, and a look ahead", The Journal of Positive Psychology, Vol. 8 No. 2, pp. 153-164.

Muthén, B. (2010), Bayesian Analysis in Mplus: A brief introduction, Mplus Technical Report, available at: http:nnwww.statmodel.com (accessed 22 July 2013).

Muthén, B.O., Muthén, L.K. (2004), Mplus, Muthén \& Muthén, Los Angeles, CA [computer software].

Muthén, L.K., Muthén, B.O. (2013), Mplus user's guide, Muthén \& Muthén, Los Angeles, CA.

Park, J.S., Kim, T.H. (2009), "Do types of organisational culture matter in nurse job satisfaction and turnover intention?", Leadership Health Services, Vol. 22 No. 1, pp. 20-38. DOI:http://dx.doi.org/10.1108/17511870910928001

Pearce, C.L., Sims, H.P. (2002), "Vertical versus shared leadership as predictors of the effectiveness of change management teams: An examination of aversive, directive, transactional, transformational, and empowering leader behaviors", Group Dynamics: Theory, Research, and Practice, Vol. 6 No. 2, pp. 172-97. DOI:http://dx.doi. org/10.1037/1089-2699.6.2.172

Preacher, K.J., Hayes, A.F. (2008), "Asymptotic and resampling strategies for assessing and comparing indirect effects in multiple mediator models", Behavior Research Methods, Vol. 40 No. 3, pp. 879-891. DOI:http://dx.doi.org/10.3758/BRM.40.3.879

Quinn, R.E., Spreitzer, G.M. (1997), "The road to empowerment: Seven questions every leader should consider", Organizational Dynamics, Vol. 26 No. 2, pp. 37-49. DOI:http://dx.doi.org/10.1016/S0090-2616(97)90004-8

Raub, S., Robert, C. (2010), "Differential effects of empowering leadership on in-role and extra-role employee behaviors: Exploring the role of psychological empowerment and power values", Human Relations, Vol. 63 No. 11, pp. 1743-1770. DOI:http:// dx.doi.org/10.1177/0018726710365092

Rothmann, S. (2010), The reliability and validity of measuring instruments of happiness in the Southern African context, North-West University, Vanderbijlpark, SA.

Satorra, A., Bentler, P.M. (2010), "Ensuring positiveness of the scaled difference chisquare test statistic", Psychometrika, Vol. 75 No. 2, pp. 243-248. DOI:http://dx.doi. org/10.1007/s11336-009-9135-y

Schaufeli, W.B., Bakker, A.B. (2004), "Job demands, job resources and their relationship with burnout and engagement: A multi-sample study", Journal of Organizational Behavior, Vol. 25 No. 3, pp. 293-315. DOI:http://dx.doi.org/10.1002/job.248

Schreiber, J.B. (2008), "Core reporting practices in structural equation modeling", Administrative Pharmacy, Vol. 4 No. 2, 83-97. DOI:http://dx.doi.org/10.1016/j. sapharm.2007.04.003

Seibert, S.E., Wang, G., Courtright, S.H. (2011), "Antecedents and consequences of psychological and team empowerment in organizations: A meta-analytic review", Journal of Applied Psychology, Vol. 96 No. 5, pp. 981-1003. DOI:http://dx.doi. org/10.1037/a0022676 
Siong, Z.M.B., Mellor, D., Moore, K.A., Firth, L. (2006), "Predicting intention to quit in the call centre industry: Does the retail model fit?", Journal of Managerial Psychology, Vol. 21 No. 3, pp. 231-243. DOI:http://dx.doi.org/10.1108/02683940610659579

Sjöberg, A., Sverke, M. (2000), “The interactive effect of job involvement and organizational commitment on job turnover revisited: A note on the mediating role of turnover intention", Scandinavian Journal of Psychology, Vol. 41 No. 3, pp. 247-252. DOI:http://dx.doi.org/10.1111/1467-9450.00194

Spreitzer, G.M. (1995), "Psychological empowerment in the workplace: Dimensions, measurement, and validation", Academy of Management Journal, Vol. 38 No. 5, pp. 1442-1465. DOI:http://dx.doi.org/10.2307/2568665

Srivastava, A., Bartol, K.M., Locke, E.A. (2006), "Empowering leadership in management teams: Effects on knowledge sharing, efficacy, and performance", Academy of Management Journal, Vol. 49 No. 6, pp. 1239-1251. DOI:http://dx.doi.org/10.5465/ AMJ.2006.23478718

Stander, M.W., Rothmann, S. (2010), "Psychological empowerment, job insecurity and employee engagement", South African Journal of Industrial Psychology, Vol. 36 No. 1, pp. 1-8.

Steger, F.M., Littman-Ovadia, H., Miller, M., Menger, L., Rothmann, S. (2013), "Engaging in work even when it is meaningless: Positive affective disposition and meaningful work interact in relation to work-engagement", Journal of Career Assessment, Vol. 21 No. 2, pp. 348-361. DOI:http://dx.doi.org/10.1177/1069072712471517

Thomas, K.W., Velthouse, B.A. (1990), "Cognitive elements of empowerment: An 'interpretive' model of intrinsic task motivation", Academy of Management Review, Vol. 15 No. 4, pp. 666-681.

Van Dierendonck, D., Dijkstra, M. (2012), "The role of the follower in the relationship between empowering leadership and empowerment: A longitudinal investigation", Journal of Applied Social Psychology, Vol. 42 No. 1, pp. 1-20. DOI:http://dx.doi. org/10.1111/j.1559-1816.2012.01022.x

Van Schalkwyk, S., Du Toit, D.H., Bothma, A.S., Rothmann, S. (2010), "Job insecurity, leadership empowerment behaviour, employee engagement and intention to leave in a petrochemical laboratory", South African Journal of Human Resource Management, Vol. 8 No. 1, pp. 234-241.

Wallace, J.C., Johnson, P.D., Mathe, K., Paul, J. (2011), "Structural and psychological empowerment climates, performance, and the moderating role of shared felt accountability", Journal of Applied Psychology, Vol. 96 No. 4, pp. 840-850. DOI:http:// dx.doi.org/10.1037/a0022227

Zbierowski, P. (2011), "The positive potential of high performance organization", Journal of Positive Management, Vol. 2 No. 1, pp. 94-108.

Zhang, X., Bartol, K.M. (2010), "Linking empowering leadership and employee creativity: The influence of psychological empowerment, intrinsic motivation and creative process engagement", Academy of Management Journal, Vol. 53 No. 1, pp. 107-128. DOI:http://dx.doi.org/10.5465/AMJ.2010.48037118

Yukl, G.A., Becker, W.S. (2006), "Effective empowerment in organizations", Organization Management Journal, Vol. 3 No. 3, pp. 210-231. DOI:http://dx.doi.org/10.1057/ omj.2006.20 